\title{
Development
}

\section{of a hydroxamamide-based bifunctional chelating agent to prepare technetium-99m-labeled bivalent ligand probes}

\author{
Yoichi Shimizu ${ }^{1,2,3 凶}$, Masato Ando $^{1,3}$, Shimpei likuni ${ }^{1}$, Hiroyuki Watanabe ${ }^{1}$ \& Masahiro Ono ${ }^{1 凶}$
}

Hydroxamamide (Ham) is a thiol-free chelating agent that forms technetium-99m $\left({ }^{99 \mathrm{~m}} \mathrm{Tc}\right)$-complexes with a metal-to-ligand ratio of 1:2 under moderate reaction conditions. Therefore, Ham-based chelating agents will produce ${ }^{99 \mathrm{~m}} \mathrm{Tc}$-labeled compounds with a bivalent targeting scaffold. For their universal usage, we developed a novel Ham-based bifunctional chelating agent, "Ham-Mal", with a maleimide group that can easily conjugate with a thiol group, for to preparing ${ }^{99 \mathrm{~m}} \mathrm{Tc}$-labeled bivalent ligand probes. Ham-Mal was synthesized by a four-step reaction, and then reacted with cysteine or $c(\mathrm{RGDFC})$ to produce $\mathrm{Ham}$-Cys or $\mathrm{Ham}-\mathrm{RGD}$. These precursors were reacted with ${ }^{99 \mathrm{~m}} \mathrm{TcO}_{4}-$ for $10 \mathrm{~min}$ under room temperature to obtain ${ }^{99 \mathrm{~m}} \mathrm{Tc}-(\mathrm{Ham}-\mathrm{Cys})_{2}$ and ${ }^{99 \mathrm{~m}} \mathrm{Tc}-(\mathrm{Ham}-\mathrm{RGD})_{2}$. The cellular uptake level of $\left.{ }^{99 \mathrm{~m} T c-(H a m-R G D)}\right)_{2}$ by U87MG (high Integrin $\mathrm{a}_{\mathrm{v}} \beta_{3}$ expression) cells was significantly higher than that by PC3 (low Integrin $\alpha_{v} \beta_{3}$ expression) cells at $60 \mathrm{~min}$ after the incubation, and the uptake was significantly suppressed by pre-treatment for $15 \mathrm{~min}$ with excess $C$ (RGDfK) peptide. In the in vivo study with U87MG/PC3 dual xenografted BALB/C-nu mice, the radioactivity of U87MG tumor tissue was significantly higher than that of PC3 tumor tissue at $360 \mathrm{~min}$ after the administration of ${ }^{99 \mathrm{~m}} \mathrm{Tc}$ (Ham-RGD $)_{2}$. These results suggest Ham-Mal may have potential as a bifunctional chelating agent for ${ }^{99 \mathrm{~m}} \mathrm{Tc}$-labeled bivalent ligand probes.

Technetium-99m $\left({ }^{99 \mathrm{~m}} \mathrm{Tc}\right)$ is one of the major radioisotopes widely used for clinical single-photon emission computed tomography (SPECT) imaging because it emits gamma rays with a photon energy of $141-\mathrm{keV}$, which is suitable for detection by the SPECT scanner, and it is easily produced by a molybdenum-99/technetium-99m generator ${ }^{1}$. To radiolabel ${ }^{99 \mathrm{~m}} \mathrm{Tc}$, many chelating moieties have been developed and used widely ${ }^{2-4}$.

Hydroxamamide (Ham) is a thiol-free chelating agent of oxo-technetium(V) $[\mathrm{Tc}(\mathrm{V})]$ known to produce ${ }^{99} \mathrm{~m}$ Tc-complexes with a high radiochemical yield under moderate reaction conditions ${ }^{5-8}$. In addition, Ham makes it possible to easily produce ${ }^{99 \mathrm{~m}}$ Tc-labeled compounds with a bivalent targeting scaffold because it forms ${ }^{99 \mathrm{~m}} \mathrm{Tc}$-complexes with a metal-to-ligand ratio of $1: 2^{7}$. Our group previously developed Ham-based ${ }^{99 \mathrm{~m}} \mathrm{Tc}$ radiolabeled SPECT imaging probes and demonstrated their properties for detecting their target biomolecules ${ }^{9-13}$. In these probes, the Ham group was directly incorporated into their chemical structures, that is to say, the reaction for induction of Ham group was not independent on the synthesis of those probes in most cases. Therefore, to develop novel Ham-based ${ }^{99 \mathrm{~m}} \mathrm{Tc}$ radiolabeled probes with other targeting ligands, synthetic routes for the probes must be redesigned and established, which makes them difficult to produce. Bifunctional chelating agents composed of a metal binding moiety and a chemically reactive functional group simplify the introduction of chelating moieties to the targeting ligands ${ }^{14}$. However, no Ham-based bifunctional chelating agent for producing ${ }^{99 m}$ Tc-labeled bivalent ligand probes has been reported.

In this study, we designed and synthesized a novel Ham-based bifunctional chelating agent "Ham-Mal" to simplify the development of Ham-based SPECT imaging probes (Fig. 1). As a chemically reactive functional

${ }^{1}$ Department of Patho-Functional Bioanalysis, Graduate School of Pharmaceutical Sciences, Kyoto University, 46-29, Yoshida Shimoadachi-cho, Sakyo-ku, Kyoto 606-8501, Japan. ${ }^{2}$ Department of Diagnostic Imaging and Nuclear Medicine, Graduate School of Medicine, Kyoto University, 54 Shogoin-kawahara-cho, Sakyo-ku, Kyoto 606-8507, Japan. ${ }^{3}$ These authors contributed equally: Yoichi Shimizu and Masato Ando ${ }^{\square}$ email: yoichis@ kuhp.kyoto-u.ac.jp; ono@pharm.kyoto-u.ac.jp 


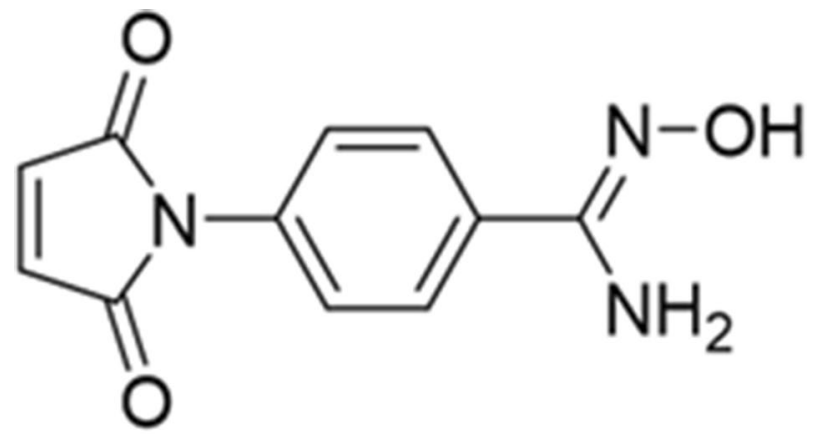

Figure 1. Chemical structure of Ham-Mal.

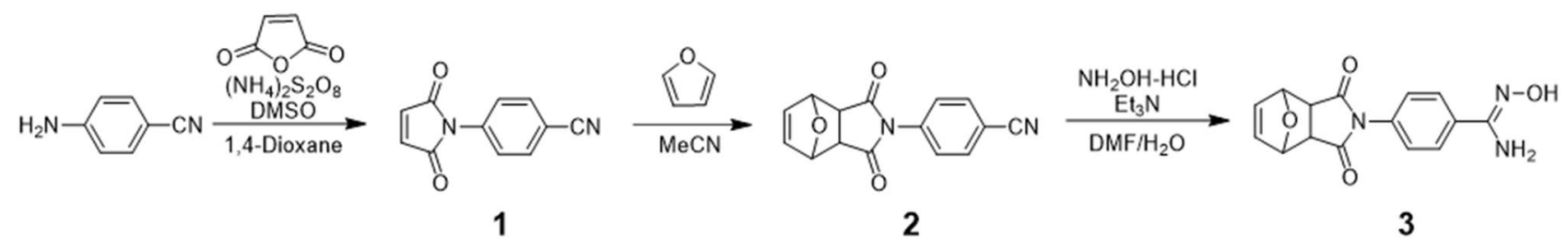

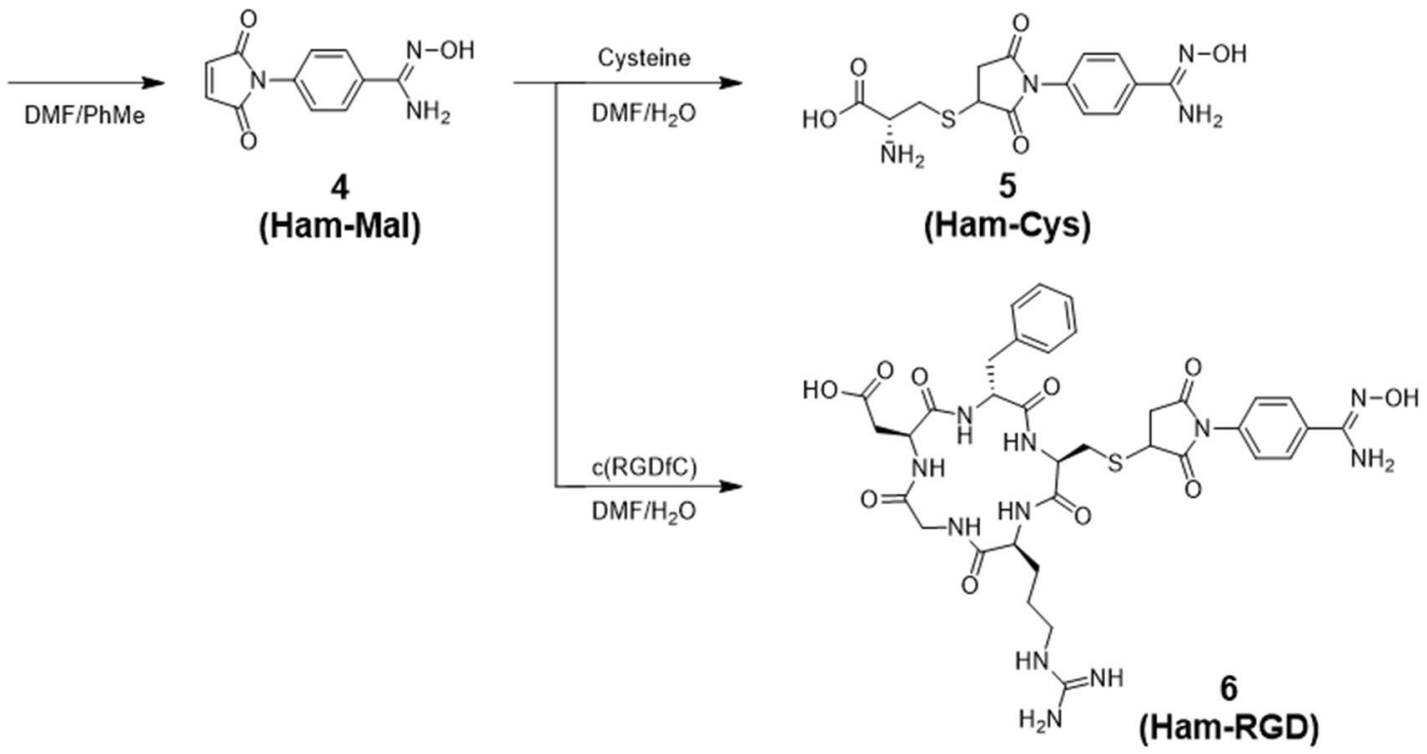

Figure 2. Synthetic route of Ham-Mal, Ham-Cys, and Ham-RGD.

group, we chose the maleimide group, which can be easily reacted with thiol groups of ligands via Thio-Michael addition under moderate conditions ${ }^{15}$. To estimate the conditions of the ${ }^{99 \mathrm{~m}} \mathrm{Tc}$ radiolabeling reaction, we synthesized "Ham-Cys", which was acquired by the reaction with Ham-Mal and cysteine, and then performed the ${ }^{99 \mathrm{~m}} \mathrm{Tc}$ radiolabeling reaction to produce " $99 \mathrm{~m} \mathrm{Tc}-(\mathrm{Ham}-\mathrm{Cys})_{2}$ " under several reaction conditions. In addition, to evaluate the utility of Ham-Mal as a ${ }^{99 \mathrm{~m}} \mathrm{Tc}$-bifunctional chelating agent, we synthesized "99m Tc-(Ham-RGD)," whose precursor, "Ham-RGD", was acquired by reacting Ham-Mal with c(RGDfC), a cyclic arginine-glycineaspartic acid (RGD) peptide with a high affinity to Integrin $\alpha_{v} \beta_{3}$, a member of the integrin superfamily of adhesion molecules ${ }^{16}$.

\section{Results}

Chemistry. The synthesis of Ham-Mal, Ham-Cys, and Ham-RGD is outlined in Fig. 2. Ham-Mal was prepared in four steps from 4-aminobenzonitrile. First, 4-aminobenzonitrile was reacted with maleic anhydride to acquire $\mathbf{1}$ and then its maleimide group was protected by furan to produce 2 . A Ham group was then introduced into 2 by reacting with hydroxylamine to produce 3. Next, Ham-Mal (4) was acquired by deprotecting the maleimide group of 3 , with a total yield of $7.2 \%$ from 4 -aminobenzonitrile. Ham-Cys and Ham-RGD were acquired by reacting Ham-Mal (4) with cysteine and c(RGDFC), with yields of $23 \%$ and $64 \%$, respectively. 


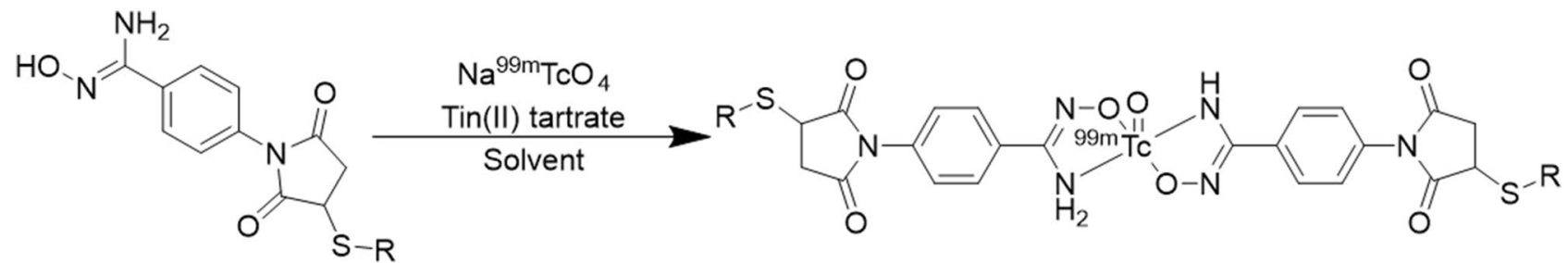

Ham-Cys

Ham-RGD<smiles>CC[C@H](N)C(=O)O</smiles>

(Ham-Cys)

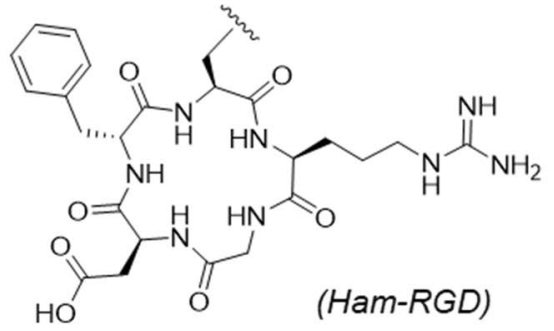

Figure 3. ${ }^{99 \mathrm{~m}} \mathrm{Tc}$ labeling route of ${ }^{99 \mathrm{~m}} \mathrm{Tc}-(\mathrm{Ham}-\mathrm{Cys})_{2}$ and ${ }^{99 \mathrm{~m}} \mathrm{Tc}-(\mathrm{Ham}-\mathrm{RGD})_{2}$.

\begin{tabular}{|l|l|l|}
\hline Solvent & Final concentration of Ham-Cys (mM) & Radiochemical yield (\%) \\
\hline \multirow{2}{*}{ Phosphate buffer (pH 7.4,10 mM) } & 10 & $68.7 \pm 2.4$ \\
\cline { 2 - 3 } & 20 & $75.3 \pm 4.5$ \\
\hline \multirow{2}{*}{ Acetic acid/ethanol (1/4) } & 10 & $10.4 \pm 9.8$ \\
\cline { 2 - 3 } & 20 & $11.0 \pm 5.0$ \\
\hline
\end{tabular}

Table 1. Radiochemical yields of ${ }^{99 \mathrm{~m}} \mathrm{Tc}$-(Ham-Cys $)_{2}$ under each condition. Each value is the mean \pm standard error of three independent experiments.
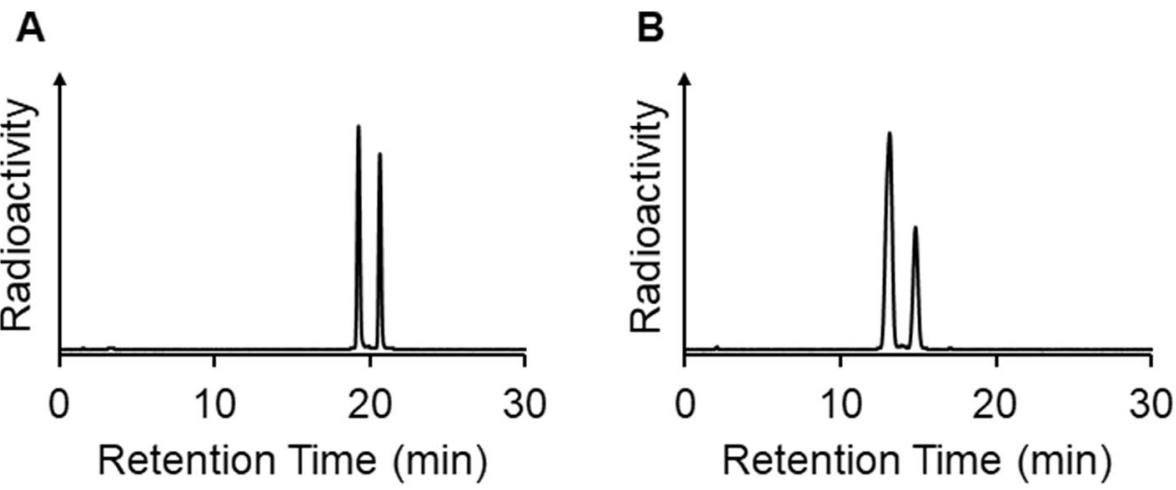

Figure 4. Radiochromatograms for ${ }^{99 \mathrm{~m}} \mathrm{Tc}-(\mathrm{Ham}-\mathrm{Cys})_{2}$ (A) and ${ }^{99 \mathrm{~m}} \mathrm{Tc}-(\mathrm{Ham}-\mathrm{RGD})_{2}$ (B).

Radiolabeling. The ${ }^{99 \mathrm{~m}} \mathrm{Tc}$ labeling of Ham-Cys was performed by reacting it with ${ }^{99 \mathrm{~m}} \mathrm{Tc}$ pertechnetate and tin(II) tartrate hydrate as a reducing agent in a solvent of acetic acid/ethanol (1/4) or phosphate buffer ( $\mathrm{pH} 7.4)$, with different final concentrations of Ham-Cys $\left(10\right.$ or $20 \mathrm{mM}$ ) (Fig. 3). The radiochemical yields of ${ }^{99 \mathrm{~m}} \mathrm{Tc}-(\mathrm{Ham}-$ Cys $)_{2}$ reacted in phosphate buffer were markedly higher than those in acetic acid/ethanol solvent [phosphate buffer: $68.7 \pm 2.4 \%$ (final concentration of Ham-Cys: $10 \mathrm{mM}$ ), $75.3 \pm 4.5 \%(20 \mathrm{mM}$ ), acetic acid/ethanol solvent: $10.4 \pm 9.8 \%(10 \mathrm{mM}), 11.0 \pm 5.0 \%(20 \mathrm{mM})]$ (Table 1). On the other hand, the concentration of the precursor (Ham-Cys) did not affect the radiochemical yield (Table 1). ${ }^{99 \mathrm{~m}} \mathrm{Tc}-(\mathrm{Ham}-\mathrm{RGD})_{2}$ was obtained by reacting HamRGD (final concentration: $10 \mathrm{mM}$ ) with ${ }^{99} \mathrm{~m}$ Tc pertechnetate and tin(II) tartrate hydrate as a reducing agent in the solvent of phosphate buffer ( $\mathrm{pH} 7.4$ ), with a radiochemical yield of a $49.0 \pm 4.8 \%$ and radiochemical purity of over $95 \%$ (Fig. 4). We also confirmed the purified ${ }^{99 \mathrm{~m}} \mathrm{Tc}-(\mathrm{Ham}-\mathrm{Cys})_{2}$ and ${ }^{99 \mathrm{~m}} \mathrm{Tc}-(\mathrm{Ham}-\mathrm{RGD})_{2}$ did not contained the respective precursor (Ham-Cys and Ham-RGD, respectively) (Supplementary file, Figure S1). 


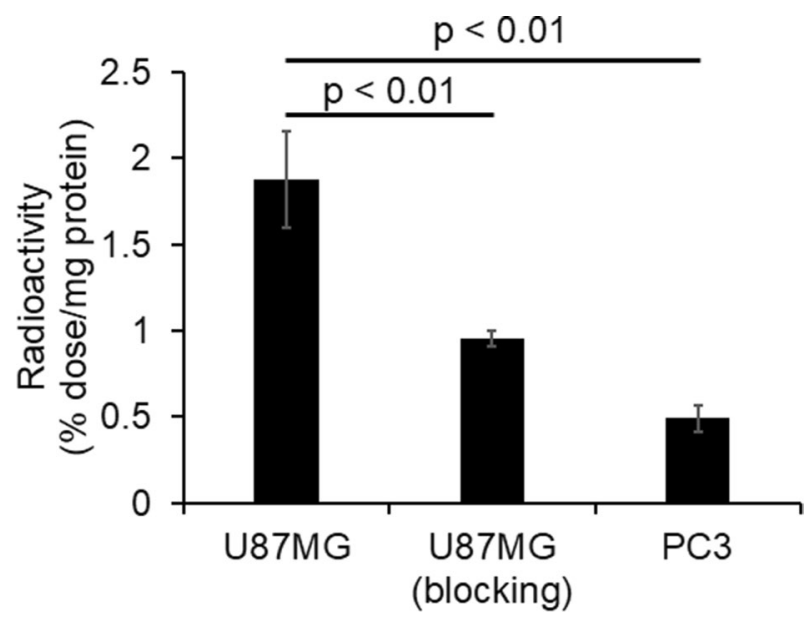

Figure 5. In vitro cellular binding of $\left.{ }^{99 \mathrm{~m} T c-(H a m-R G D)}\right)_{2}$ in U87MG and PC3 cells. Results are expressed as the mean \pm standard error of six independent experiments.

\begin{tabular}{|l|l|l|l|l|}
\hline \multirow{2}{*}{ Organ } & \multicolumn{4}{l}{ Time after injection } \\
\cline { 2 - 5 } & $\mathbf{5} \mathbf{~ m i n}$ & $\mathbf{6 0} \mathbf{~} \mathbf{l}$ & $\mathbf{1 8 0} \mathbf{~}$ in & $\mathbf{3 6 0} \mathbf{~ m i n}$ \\
\hline Blood & $14.38 \pm 0.83$ & $9.77 \pm 1.73$ & $7.17 \pm 1.46$ & $5.90 \pm 0.51$ \\
\hline Spleen & $2.72 \pm 0.05$ & $3.23 \pm 0.57$ & $3.01 \pm 0.53$ & $3.92 \pm 0.63$ \\
\hline Pancreas & $1.60 \pm 0.11$ & $1.56 \pm 0.30$ & $1.34 \pm 0.21$ & $1.33 \pm 0.25$ \\
\hline Stomach ${ }^{\mathrm{a}}$ & $1.07 \pm 0.25$ & $1.58 \pm 0.28$ & $1.62 \pm 0.36$ & $1.45 \pm 0.19$ \\
\hline Intestine & $1.62 \pm 0.11$ & $3.51 \pm 0.46$ & $6.87 \pm 1.06$ & $10.62 \pm 1.72$ \\
\hline Kidney & $6.93 \pm 0.50$ & $12.22 \pm 1.78$ & $10.98 \pm 1.73$ & $12.89 \pm 1.88$ \\
\hline Liver & $4.05 \pm 0.19$ & $4.67 \pm 1.04$ & $4.12 \pm 0.62$ & $4.59 \pm 0.72$ \\
\hline Heart & $3.33 \pm 0.37$ & $3.21 \pm 0.48$ & $2.44 \pm 0.49$ & $2.63 \pm 0.39$ \\
\hline Lung & $7.84 \pm 1.34$ & $6.17 \pm 1.12$ & $5.14 \pm 0.97$ & $4.93 \pm 0.72$ \\
\hline Brain & $0.35 \pm 0.02$ & $0.35 \pm 0.10$ & $0.28 \pm 0.04$ & $0.05 \pm 0.01$ \\
\hline Muscle & $0.82 \pm 0.17$ & $1.04 \pm 0.28$ & $0.94 \pm 0.26$ & $0.91 \pm 0.10$ \\
\hline Thyroid ${ }^{\mathrm{a}}$ & $0.04 \pm 0.01$ & $0.09 \pm 0.02$ & $0.06 \pm 0.04$ & $0.05 \pm 0.01$ \\
\hline U87MG & $2.26 \pm 0.71$ & $6.80 \pm 0.78$ & $6.75 \pm 1.73$ & $10.01 \pm 1.89$ \\
\hline PC3 & $0.56 \pm 0.09$ & $1.08 \pm 0.20$ & $1.30 \pm 0.35$ & $1.36 \pm 0.14$ \\
\hline
\end{tabular}

Table 2. Biodistribution of ${ }^{99 \mathrm{~m}} \mathrm{Tc}-(\mathrm{Ham}-\mathrm{RGD})_{2}$ in the U87MG/PC3 tumor-bearing mice. Values are expressed as the $\%$ injected dose per gram $(\% \mathrm{ID} / \mathrm{g})$ of organ tissue. Each value is the mean \pm standard deviation of $4-5$ mice at each interval. ${ }^{a}$ Values are expressed as the \% injected dose (\%ID).

In vitro cellular uptake study. The cellular uptake of ${ }^{99 \mathrm{~m}} \mathrm{Tc}-(\mathrm{Ham}-\mathrm{RGD})_{2}$ is expressed as the \%dose/mg protein (Fig. 5). The radioactivity of U87MG cells was significantly higher than that of PC3 cells (U87MG: $1.87 \pm 0.28$ vs. PC $3: 0.49 \pm 0.08 \%$ dose/mg protein, $\mathrm{p}<0.01)$. In addition, the radioactivity of U87MG cells was significantly reduced by pretreatment with excess c(RGDfK) $(0.95 \pm 0.04 \%$ dose/mg protein, p $<0.01)$ (Fig. 5).

In vitro stability of ${ }^{99 \mathrm{~m}} \mathrm{Tc}-(\mathrm{Ham}-\mathrm{RGD})_{2}$ in mouse plasma. The in vitro stability of ${ }^{99 \mathrm{~m}} \mathrm{Tc}-(\mathrm{Ham}-\mathrm{RGD})_{2}$ in mouse plasma was evaluated by incubating the probe in murine plasma at $37{ }^{\circ} \mathrm{C}$ for 60 and $180 \mathrm{~min}$. The radiochemical purity of ${ }^{99 \mathrm{~m}} \mathrm{Tc}-(\mathrm{Ham}-\mathrm{RGD})_{2}$ was $37.3 \pm 3.7 \%(60 \mathrm{~min})$ and $15.7 \pm 5.8 \%$ (180 min), respectively.

In vivo biodistribution. The uptake of ${ }^{99} \mathrm{~m} \mathrm{Tc}-(\mathrm{Ham}-\mathrm{RGD})_{2}$ in each organ was expressed as the \%ID/g, except for that in the stomach and thyroid, which was expressed as the \%ID (Table 2). ${ }^{99 \mathrm{~m} T c-(H a m-R G D)}{ }_{2}$ was excreted mainly from the kidneys. The radioactivity of U87MG tumors (high Integrin $\mathrm{a}_{\mathrm{v}} \beta_{3}$ expression) was significantly higher than that of PC3 tumors from $5 \mathrm{~min}$ after the administration of ${ }^{99 \mathrm{~m}} \mathrm{Tc}-(\mathrm{Ham}-\mathrm{RGD})_{2}$. In addition, the accumulation in U87MG tumors was reduced by blocking with excess c(RGDfK) at $180 \mathrm{~min}$ after administration $[6.75 \pm 1.73 \% \mathrm{ID} / \mathrm{g}$ (non-blocking) vs. $4.00 \pm 0.68 \% \mathrm{ID} / \mathrm{g}$ (blocking) $(\mathrm{p}<0.01)]$, but there was no significant difference in accumulation in PC3 tumors between the non-blocking and blocking groups $[1.30 \pm 0.35 \% \mathrm{ID} / \mathrm{g}$ (non-blocking) vs. $1.29 \pm 0.12 \% \mathrm{ID} / \mathrm{g}$ (blocking) $(\mathrm{p}=1.00)]$ (Supplementary file, Table S1). 
$60 \mathrm{~min}$
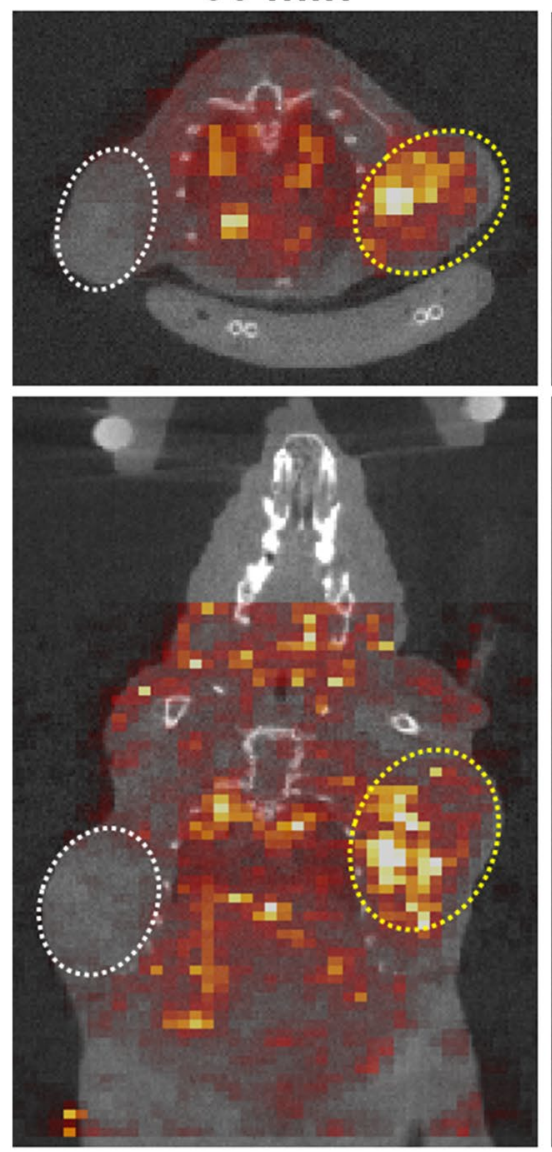

$180 \mathrm{~min}$
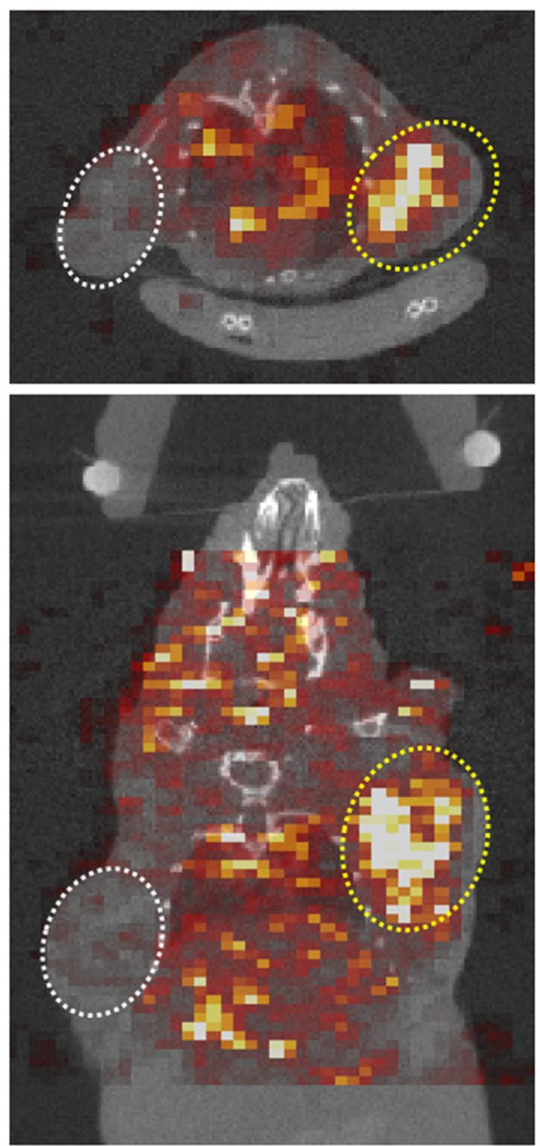

$\operatorname{Max}$

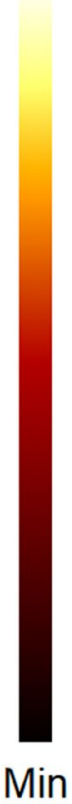

Figure 6. SPECT/CT images (upper: axial, lower: coronal) of the U87MG/PC3 tumor-bearing mouse after the administration of $\left.{ }^{99 \mathrm{~m} T c-(H a m-R G D)}\right)_{2} .{ }^{99 \mathrm{~m}} \mathrm{Tc}-(\mathrm{Ham}-\mathrm{RGD})_{2}(2.8 \mathrm{MBq} / 0.1 \mathrm{~mL}$ saline) was injected intravenously into the mouse, and the SPECT imaging was acquired at 60 (left) and $180 \mathrm{~min}$ (right) after the administration. The CT images were acquired just before the SPECT imaging. The Yellow circle: U87MG tumor, white circle: PC3 tumor.

SPECT imaging. The SPECT/CT images were acquired at 60 and $180 \mathrm{~min}$ after the administration of ${ }^{99 \mathrm{~m} T c-}$

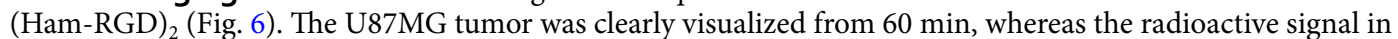
the PC3 tumor was limited.

\section{Discussion}

In this study, we designed and synthesized "Ham-Mal" as a novel Ham-based bifunctional chelating agent for ${ }^{99 m}$ Tc. Ham-Mal was obtained through a four-step reaction from 4 -aminobenzonitrile with a total yield of $7.2 \%$ (Fig. 2). We first converted the cyanide group of $\mathbf{1}$ to the Ham group directly; however, this reaction failed, possibly due to the instability of the maleimide group of $\mathbf{1}$. Maleimide groups can be protected and deprotected with furan by the thermally reversible Diels-Alder click reaction ${ }^{17}$. Thus, the Ham group was introduced after protecting the maleimide group of $\mathbf{1}$. After the synthesis of Ham-Mal, we conjugated ligands [cysteine and $c($ RGDfC)] having a thiol group with Ham-Mal via the thiol-maleimide reaction, and obtained Ham-Cys and Ham-RGD, respectively (Fig. 2).

Next, we performed the radiolabeling of Ham-Cys and Ham-RGD with ${ }^{99} \mathrm{TcO}_{4}^{-}$. In general, the Ham group structure is known to have two tautomer, and thus the ${ }^{99 \mathrm{~m}} \mathrm{Tc}-\mathrm{Ham}$ complex forms two tautomer which can be observed by RP-HPLC ${ }^{7}$. The chelation of Ham and ${ }^{99 \mathrm{~m}} \mathrm{Tc}$ was confirmed by the disappearance of the peak from ${ }^{99} \mathrm{TcO}_{4}^{-}$(retention time: $2-4 \mathrm{~min}^{11}$ ) and then the appearance of two peaks because it is difficult to synthesize the analogues of the rhenium-Ham complex ${ }^{7}$. To search for an appropriate ${ }^{99 \mathrm{~m}} \mathrm{Tc}$ radiolabeling reaction condition, we first evaluated the reaction of Ham-Cys and ${ }^{99} \mathrm{mcO}_{4}{ }^{-}$with different concentrations of Ham-Cys (final concentration: 10 and $20 \mathrm{mM}$ ) in different solvents [phosphate buffer $(\mathrm{pH} 7.4)$ and acetic acid/ethanol = 1/4]. In our previous study, we used an acetic acid/ethanol mixture as the solvent for ${ }^{99 \mathrm{~m}} \mathrm{Tc}$ radiolabeling reactions of compounds containing $\mathrm{Ham}^{9-13}$ to prevent forming by-products (especially, ${ }^{99 \mathrm{~m}} \mathrm{Tc}$-colloid); however, the radiochemical yields were low [10.4 $\pm 9.8 \%$ (final concentration of Ham-Cys:10 mM), $11.0 \pm 5.0 \%(20 \mathrm{mM})]$ (Table1) and the acquired ${ }^{99 \mathrm{~m}} \mathrm{Tc}$-radiolabeled compound was unstable. On the other hand, ${ }^{99 \mathrm{~m}} \mathrm{Tc}$ radiolabeling reaction 
to give ${ }^{99 \mathrm{~m}} \mathrm{Tc}-(\mathrm{Ham}-\mathrm{Cys})_{2}$ in phosphate buffer ( $\left.\mathrm{pH} 7.4\right)$ proceeded with radiochemical yields of $68.7 \pm 2.4 \%$ (final concentration of Ham-Cys: $10 \mathrm{mM}$ ) and $75.3 \pm 4.5 \%(20 \mathrm{mM})$ (Table 1). The acquired ${ }^{99 \mathrm{~m}}$ Tc-radiolabeled compound was analyzed by RP-HPLC and only two radioactive peaks (retention times: $19.2 \mathrm{~min}$ and $20.6 \mathrm{~min}$ ) were observed (Fig. 4A). Therefore, this suggested that the ${ }^{99 \mathrm{~m}} \mathrm{Tc}$-radiolabeling reaction of compounds based on Ham-Mal proceeded in the neutral $\mathrm{pH}$ solvent. As for the concentration of the precursor, a final concentration of $10 \mathrm{mM}$ was considered sufficient for the ${ }^{99 \mathrm{~m}} \mathrm{Tc}$-radiolabeling reaction (Table 1 ). Thus, we performed the radiolabeling of Ham-RGD with ${ }^{99 \mathrm{~m}} \mathrm{Tc}$ using $10 \mathrm{mM}$ (final concentration) Ham-RGD in phosphate buffer (pH 7.4), and acquired ${ }^{99 \mathrm{~m}} \mathrm{Tc}$-(Ham-RGD) ${ }_{2}$ in a radiochemical yield of a $47 \%$ with a radiochemical purity of over $95 \%$ (Fig. 4B).

To confirm that ${ }^{99 \mathrm{~m}} \mathrm{Tc}$-radiolabeled agents composed of Ham-Mal are able to target the biomolecules to which the ligands conjugated to Ham-Mal have a high affinity, we next performed in vitro and in vivo studies with ${ }^{99} \mathrm{~m}$ Tc-(Ham-RGD) ${ }_{2}$, and evaluated it as an Integrin $\alpha_{v} \beta_{3}$-targeting probe. Integrin $\alpha_{v} \beta_{3}$ is a well-known biomolecule that is closely related to the neovasculature and metastasis of cancer ${ }^{18}$. In addition, $c(R G D f C)$, a targeting ligand of ${ }^{99 \mathrm{~m}} \mathrm{Tc}$-(Ham-RGD) $)_{2}$, is known to have a high affinity to Integrin $\mathrm{a}_{\mathrm{v}} \beta_{3}{ }^{19}$. In the in vitro study, the cellular uptake level of ${ }^{99 \mathrm{~m}} \mathrm{Tc}$-(Ham-RGD) ${ }_{2}$ in U87MG cells (high Integrin $\alpha_{\mathrm{v}} \beta_{3}$ expression) was significantly higher than that in PC3 cells (low Integrin $\mathrm{a}_{\mathrm{v}} \beta_{3}$ expression) (U87MG: $1.87 \pm 0.28$ vs. PC3: $0.49 \pm 0.08 \% \mathrm{dose} / \mathrm{mg}$ protein, $\mathrm{p}<0.01$ ) (Fig. 5). In addition, the uptake level of ${ }^{99 \mathrm{~m}} \mathrm{Tc}-(\mathrm{Ham}-\mathrm{RGD})_{2}$ in U87MG cells was significantly reduced by pretreatment with excess non-radiolabeled cyclic RGD peptide [c(RGDfK)] $(0.95 \pm 0.04 \%$ dose/mg protein, $\mathrm{p}<0.05)$ (Fig. 5). This suggests that ${ }^{99 \mathrm{~m}} \mathrm{Tc}-(\mathrm{Ham}-\mathrm{RGD})_{2}$ was taken up specifically by cells with high Integrin $\alpha_{v} \beta_{3}$ expression.

In the in vivo biodistribution study, ${ }^{99 \mathrm{~m}} \mathrm{Tc}-(\mathrm{Ham}-\mathrm{RGD})_{2}$ also accumulated highly in U87MG tumors compared with PC3 tumors from 5 min after its i.v. administration (Table 2). In addition, the accumulation level in U87MG tumors was reduced by blocking with excess non-radiolabeled c(RGDfK) at $180 \mathrm{~min}$ after administration $[4.00 \pm 0.68 \% \mathrm{ID} / \mathrm{g}$ (blocking) $(\mathrm{p}<0.05)]$ (Supplementary file, Table S1), which suggests that ${ }^{99 \mathrm{~m} T c}$ - $(\mathrm{Ham}-\mathrm{RGD})_{2}$ accumulated specifically in tumors with high Integrin $\alpha_{v} \beta_{3}$ expression. We also performed SPECT/CT imaging study of ${ }^{99 \mathrm{~m}} \mathrm{Tc}-(\mathrm{Ham}-\mathrm{RGD})_{2}$, and confirmed that ${ }^{99 \mathrm{~m}} \mathrm{Tc}-(\mathrm{Ham}-\mathrm{RGD})_{2}$ can selectively visualize U87MG tumors, consistent with the in vivo biodistribution study (Fig. 6). These results support the use of ${ }^{99 \mathrm{~m}} \mathrm{Tc}-(\mathrm{Ham}-\mathrm{RGD})_{2}$ as a SPECT imaging probe targeting tumors with high Integrin $\alpha_{v} \beta_{3}$ expression. In the in vivo biodistribution study, we also observed high radioactivity in the kidneys (Table 2). This may be due to the properties of $c$ (RGDfC) because Integrin $\alpha_{v} \beta_{3}$ was reported to be expressed in the kidneys, especially in glomerular epithelial cells and Bowman's capsule ${ }^{20}$, and that the conventional agents based on RGD peptides accumulated highly in

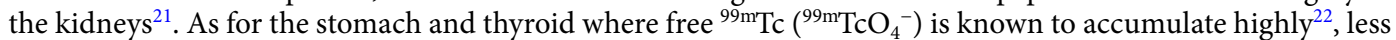
radioactivity was observed at $360 \mathrm{~min}$ after the administration of ${ }^{99 \mathrm{~m}} \mathrm{Tc}-(\mathrm{Ham}-\mathrm{RGD})_{2}$ (Table 2). We also evaluated the in vitro stability of ${ }^{99 \mathrm{~m}} \mathrm{Tc}-(\mathrm{Ham}-\mathrm{RGD})_{2}$ in mouse plasma; however, we found that the radiochemical purity decreased in a time dependent manner, and some unknown hydrophilic metabolites emerged (Figure S2). Given that other Ham-based ${ }^{99 \mathrm{~m}} \mathrm{Tc}$ radiolabeled compounds we developed previously ${ }^{11,13}$ showed high stability in plasma and good blood clearance, it is suspected that those unknown metabolites affected the slow blood clearance. Although the metabolites and the reason of the instability is still unclear, the low stability of ${ }^{99 \mathrm{~m}}$ Tc-(Ham-RGD) ${ }_{2}$ in plasma is the limitation, and further study for redesigning the bifunctional chelate to improve the stability would be needed for use it in in vivo study.

To date, several chelating groups, such as D-penicillamine $e^{23,24}$ and isocyanide ${ }^{25,26}$, have been reported to form multivalent complexes with ${ }^{99 \mathrm{~m}} \mathrm{Tc}$. These chelates reacted with ${ }^{99 \mathrm{~m}} \mathrm{Tc}$ effectively at a low concentration of the precursors, but their reaction temperature was high $\left(100-120^{\circ} \mathrm{C}\right)$. On the other hand, the precursors based on Ham-Mal reacted with ${ }^{99 \mathrm{~m}} \mathrm{Tc}$ under moderate conditions (at room temperature), which is suitable for radiolabeling thermally instable compounds such as proteins (e.g. antibody and its fragment). For radiolabeling ${ }^{99 \mathrm{~m}} \mathrm{Tc}$ with those thermally instable compounds, some chelates such as hydrazinonicotinamide (HYNIC) have been used ${ }^{27,28}$. Given that these chelates form ${ }^{99 \mathrm{~m}} \mathrm{Tc}$-complexes with a metal-to-ligand ratio of 1:1, Ham has an advantage in terms of developing ${ }^{99 \mathrm{~m}} \mathrm{Tc}$-labeled compounds with a bivalent targeting scaffold, so that Ham-Mal would be a promising bifunctional chelate for developing those ${ }^{99 \mathrm{~m}} \mathrm{Tc}$-labeled compounds.

In this study, we designed and synthesized a novel bifunctional ${ }^{99 m} \mathrm{Tc}$-chelating agent based on Ham, "HamMal". ${ }^{99 m}$ Tc radiolabeled agents were acquired easily by reacting Ham-Mal and the targeting ligands via thiolmaleimide reaction, and then by the ${ }^{99 \mathrm{~m}} \mathrm{Tc}$-radiolabeling reaction under moderate conditions. The acquired ${ }^{99 \mathrm{~m}} \mathrm{Tc}$ radiolabeled agent [ ${ }^{99 \mathrm{~m}} \mathrm{Tc}-(\mathrm{Ham}-\mathrm{RGD})_{2}$ in this study]demonstrated good visualization of specific organs expressing the target biomolecule. This study suggests that Ham-Mal is available for the development of ${ }^{99 \mathrm{~m}} \mathrm{Tc}-$ radiolabeled SPECT imaging probes containing bivalent targeting ligands.

\section{Methods}

Materials. All reagents were obtained commercially and used without further purification unless otherwise indicated. ${ }^{99 \mathrm{~m}} \mathrm{Tc}-\mathrm{NaTcO}_{4}$ was purchased from Nihon Medi-Physics Co., Ltd. (Tokyo, Japan). W-Prep 2XY (Yamazen, Osaka, Japan) was used for silica gel column chromatography on a Hi Flash silica gel column $(40 \mu \mathrm{m}, 60 \AA$, Yamazen). ${ }^{1} \mathrm{H}$ NMR and ${ }^{13} \mathrm{C}$ NMR spectra were recorded on a JNM-ECS400 (JEOL, Tokyo, Japan) with tetramethylsilane as an internal standard. Coupling constants are reported in Hertz. Multiplicity was defined as singlet (s), doublet (d), or multiplet (m). High-resolution mass spectrometry (HRMS) of fast atom bombardment (FAB) and electrospray ionization (ESI) were carried out with a JEOL JMS-700 (JEOL) and a LCMS-IT-TOF (SHIMADZU, Kyoto, Japan), respectively. High-performance liquid chromatography (HPLC) was performed with a Shimadzu system (SHIMADZU, an LC-20AT pump with an SPD-20A UV detector, $\lambda=254 \mathrm{~nm}$ ).

Chemistry. Synthesis of 1 . A solution of 4-aminobenzonitrile $(2.36 \mathrm{~g}, 20 \mathrm{mmol})$ and maleic anhydride $(5.88 \mathrm{~g}, 60 \mathrm{mmol})$ in 1,4 -dioxane $(30 \mathrm{~mL})$ was stirred at $100{ }^{\circ} \mathrm{C}$ for $1 \mathrm{~h}$. To the reaction mixture, ammonium 
persulfate $(9.12 \mathrm{~g}, 40 \mathrm{mmol})$ and dimethyl sulfoxide (DMSO) $(2.84 \mathrm{~mL})$ were added and the reaction mixture was heated to $100^{\circ} \mathrm{C}$ for $3 \mathrm{~h}$. Thereafter, the reaction mixture was filtered and dioxane was removed under vacuo. The residue was dissolved in ethyl acetate and washed with diluted $\mathrm{HCl}$, saturated aqueous $\mathrm{NaHCO}_{3}$, and brine. The organic layer was dried over $\mathrm{Na}_{2} \mathrm{SO}_{4}$ and the solvent was evaporated under vacuo to afford $3.38 \mathrm{~g}$ of $\mathbf{1}$ (yield: 85\%). ${ }^{1} \mathrm{H}$ NMR (400 MHz, DMSO-d $\left.{ }_{6}\right) \delta 7.25(\mathrm{~s}, 2 \mathrm{H}), 7.59(\mathrm{~d}, J=8.4 \mathrm{~Hz}, 2 \mathrm{H}), 7.98(\mathrm{~d}, J=8.8 \mathrm{~Hz}, 2 \mathrm{H}) .{ }^{13} \mathrm{C}$ NMR $\left(100 \mathrm{MHz}, \mathrm{DMSO}-\mathrm{d}_{6}\right) \delta 109.88,118.49,126.86,133.06,135.02,135.88,169.34$.

Synthesis of 2. A solution of $1(3.31 \mathrm{~g}, 16.7 \mathrm{mmol})$ in acetonitrile $(10 \mathrm{~mL})$ was mixed with furan $(5 \mathrm{~mL})$ and stirred at $60^{\circ} \mathrm{C}$ for $8 \mathrm{~h}$. The solvent was evaporated and ethyl acetate was added, then a solid precipitated out. The material was filtered and washed with ethyl acetate. The filtrated solution was concentrated to afford more of the product, which was also filtered and washed with ethyl acetate. The combined solid portions were dried under high vacuum at room temperature overnight to afford $2.67 \mathrm{~g}$ of 2 (yield: $60 \%)$. ${ }^{1} \mathrm{H}$ NMR (400 MHz, DMSO- $d_{6}$ ) $\delta 3.13(\mathrm{~s}, 2 \mathrm{H}), 5.26(\mathrm{~s}, 2 \mathrm{H}), 6.62(\mathrm{~s}, 2 \mathrm{H}), 7.47(\mathrm{~d}, J=8.0 \mathrm{~Hz}, 2 \mathrm{H}), 7.98(\mathrm{~d}, J=8.0 \mathrm{~Hz}, 2 \mathrm{H}) .{ }^{13} \mathrm{C} \mathrm{NMR}(100 \mathrm{MHz}$, DMSO-d $\left.{ }_{6}\right) \delta 47.71,80.91,110.98,118.29,127.55,133.19,136.05,136.72,175.27$. HR-MS (FAB, pos) $\mathrm{m} / z$ calcd. for $\mathrm{C}_{15} \mathrm{H}_{11} \mathrm{~N}_{2} \mathrm{O}_{3}{ }^{+}, 267.0770$; found $267.0768[\mathrm{M}+\mathrm{H}]^{+}$.

Synthesis of 3. A solution of hydroxylamine hydrochloride $(521 \mathrm{mg}, 7.5 \mathrm{mmol})$ and triethylamine $(1.04 \mathrm{~mL}$, $7.5 \mathrm{mmol})$ in $\mathrm{N}, \mathrm{N}$-dimethylformamide (DMF) $(5 \mathrm{~mL})$ and $\mathrm{H}_{2} \mathrm{O}(2 \mathrm{~mL})$ was added to a solution of $2(1.33 \mathrm{~g}$, $5 \mathrm{mmol})$ in DMF $(10 \mathrm{~mL})$. The reaction mixture was stirred at room temperature for $3 \mathrm{~h}$. Then, $\mathrm{H}_{2} \mathrm{O}$ was added to the solution and diluted with ethyl acetate. The organic layer was dried over $\mathrm{Na}_{2} \mathrm{SO}_{4}$ and the solvent was evaporated under vacuo. The residue was recrystallized with chloroform and dried under high vacuum at room temperature overnight to afford $287 \mathrm{mg}$ of 3 (yield: 19\%). ${ }^{1} \mathrm{H}$ NMR $\left(400 \mathrm{MHz}, \mathrm{DMSO}-d_{6}\right) \delta 3.08(\mathrm{~s}, 2 \mathrm{H}), 5.24(\mathrm{~s}$, $2 \mathrm{H}), 5.88(\mathrm{~s}, 2 \mathrm{H}), 6.60(\mathrm{~s}, 2 \mathrm{H}), 7.19(\mathrm{~d}, J=8.4 \mathrm{~Hz}, 2 \mathrm{H}), 7.74(\mathrm{~d}, J=8.4 \mathrm{~Hz}, 2 \mathrm{H}), 9.74(\mathrm{~s}, 1 \mathrm{H}) .{ }^{13} \mathrm{C} \mathrm{NMR}(100 \mathrm{MHz}$, DMSO- $\left.d_{6}\right) \delta 47.51,80.80,126.01,126.46,132.41,133.41,136.66,150.27,175.68$. HR-MS (FAB, pos) $\mathrm{m} / z$ calculated for $\mathrm{C}_{15} \mathrm{H}_{14} \mathrm{~N}_{3} \mathrm{O}_{4}^{+}, 300.0984$; found $300.0985[\mathrm{M}+\mathrm{H}]^{+}$.

Synthesis of 4 (Ham-Mal). A solution of $3(299 \mathrm{mg}, 1 \mathrm{mmol})$ in DMF $(6 \mathrm{~mL})$ and toluene $(18 \mathrm{~mL})$ was stirred at $115^{\circ} \mathrm{C}$ for $2 \mathrm{~h}$. After evaporation of the solvent, the residue was suspended in $\mathrm{H}_{2} \mathrm{O}$ and then filtered. The solid portion was dried under high vacuum at room temperature overnight to afford $231 \mathrm{mg}$ of $\mathbf{4}$ (yield: 74\%). ${ }^{1} \mathrm{H}$ NMR $\left(400 \mathrm{MHz}, \mathrm{DMSO}-d_{6}\right) \delta 5.87(\mathrm{~s}, 2 \mathrm{H}), 7.20(\mathrm{~s}, 2 \mathrm{H}), 7.33(\mathrm{~d}, J=8.4 \mathrm{~Hz}, 2 \mathrm{H}), 7.75(\mathrm{~d}, J=8.8 \mathrm{~Hz}, 2 \mathrm{H})$, $9.72(\mathrm{~s}, 1 \mathrm{H}) .{ }^{13} \mathrm{C}$ NMR $\left(100 \mathrm{MHz}\right.$, DMSO- $\left.d_{6}\right) \delta 125.85,126.28,131.94,132.65,134.73,150.29,169.82$. HR-MS (ESI, pos) $m / z$ calculated for $\mathrm{C}_{11} \mathrm{H}_{10} \mathrm{~N}_{3} \mathrm{O}_{3}{ }^{+}, 232.0722$; found $232.0725[\mathrm{M}+\mathrm{H}]^{+}$.

Synthesis of 5 (Ham-Cys). A solution of L-cysteine $(10 \mathrm{mg}, 80 \mu \mathrm{mol})$ in $\mathrm{H}_{2} \mathrm{O}(100 \mu \mathrm{L})$ was adjusted to $\mathrm{pH}$ $7-8$ by $0.1 \mathrm{M} \mathrm{NaOH}$ and then added to a solution of $4(10 \mathrm{mg}, 40 \mu \mathrm{mol})$ in DMF $(500 \mu \mathrm{L})$. The reaction mixture was stirred at room temperature for $1 \mathrm{~h}$. Then, the solvent was evaporated and the residue was purified by RP-HPLC on a Cosmosil 5C $_{18}$-AR-II column (Nacalai Tesque, Kyoto, Japan, diameter: $10 \mathrm{~mm}$, length: $250 \mathrm{~mm}$, particle size: $5 \mu \mathrm{m}$, pore size: $120 \AA)$ using the mobile phase $\left[\mathrm{H}_{2} \mathrm{O}(0.1 \%\right.$ TFA $) /$ acetonitrile $(0.1 \%$ TFA $\left.)=90 / 10\right]$ at a flow rate of $4.0 \mathrm{~mL} / \mathrm{min}$ to give $3.5 \mathrm{mg}$ of 5 (yield: $23 \%) .{ }^{1} \mathrm{H}$ NMR $\left(400 \mathrm{MHz}, \mathrm{D}_{2} \mathrm{O}\right) \delta 3.07-3.14(\mathrm{~m}, 2 \mathrm{H})$, 3.24-3.34 (m, 2H), 4.08-4.18 (m, $2 \mathrm{H}), 7.39(\mathrm{~d}, J=8.0 \mathrm{~Hz}, 2 \mathrm{H}), 7.70(\mathrm{~d}, J=8.0 \mathrm{~Hz}, 2 \mathrm{H})$. ESI-HRMS $m / z$ calculated for $\mathrm{C}_{14} \mathrm{H}_{17} \mathrm{~N}_{4} \mathrm{O}_{5} \mathrm{~S}^{+}, 353.0920$; found, $353.0919[\mathrm{M}+\mathrm{H}]^{+}$.

Synthesis of 6 (Ham-RGD). A solution of c(RGDfC) (PEPTIDE INSTITUTE, INC., Osaka, Japan, 2.0 mg, $4 \mu \mathrm{mol})$ in $\mathrm{H}_{2} \mathrm{O}(200 \mu \mathrm{L})$ was added to a solution of $4(0.8 \mathrm{mg}, 4 \mu \mathrm{mol})$ in DMF $(500 \mu \mathrm{L})$. The reaction mixture was stirred at room temperature for $1 \mathrm{~h}$. Then, the solvent was evaporated and the residue was purified by RPHPLC on a Cosmosil 5C $\mathrm{C}_{18}$-AR-II column (Nacalai Tesque, diameter: $10 \mathrm{~mm}$, length: $250 \mathrm{~mm}$, particle size: $5 \mu \mathrm{m}$, pore size: $120 \AA)$ using the mobile phase $\left[\mathrm{H}_{2} \mathrm{O}(0.1 \% \mathrm{TFA}) /\right.$ acetonitrile $(0.1 \% \mathrm{TFA})=90 / 10(0 \mathrm{~min})$ to $70 / 30(30 \mathrm{~min})]$ at a flow rate of $4.0 \mathrm{~mL} / \mathrm{min}$ to give $1.8 \mathrm{mg}$ of 6 (64\% yield). HR-MS (ESI, pos) $\mathrm{m} / z$ calculated 810.2993 , found $810.2988[\mathrm{M}+\mathrm{H}]^{+}$.

Radiolabeling of ${ }^{99 m} \mathrm{Tc}-(\mathrm{Ham}-\mathrm{Cys})_{2}$. To a solution of 5 (Ham-Cys, final concentration: $10 \mathrm{mM}$ or $20 \mathrm{mM})$ in an acetic acid/ethanol mixture $(1 / 4,50 \mu \mathrm{L})$ or phosphate buffer $(\mathrm{pH} 7.4,10 \mathrm{mM}, 50 \mu \mathrm{L}), 100 \mu \mathrm{L}$ of ${ }^{99} \mathrm{mc}^{\mathrm{T}} \mathrm{NaTcO}_{4}$ solution (18-30 MBq) and $15 \mu \mathrm{L}$ of $3 \mathrm{mM}$ tin(II) tartrate hydrate solution in $\mathrm{H}_{2} \mathrm{O}$ were added. The reaction mixture was incubated at room temperature for $10 \mathrm{~min}$ and purified by RP-HPLC on a YMC-Triart C18 (YMC CO., LTD., Kyoto, Japan, diameter: $4.6 \mathrm{~mm}$, length: $150 \mathrm{~mm}$, particle size: $5 \mu \mathrm{m}$, pore size: $120 \AA$ A ) using the mobile phase $[10 \mathrm{mM}$ phosphate buffer $(\mathrm{pH} 7.4) /$ acetonitrile $=100 / 0(0 \mathrm{~min})$ to $70 / 30(30 \mathrm{~min})]$ at a flow rate of $1.0 \mathrm{~mL} / \mathrm{min}$. The two peaks (retention time: around 19 to $20 \mathrm{~min}$, and around 20 to $21 \mathrm{~min}$ ) were collected, mixed, and used as $\left.{ }^{99 \mathrm{~m} T c-(H a m-C y s}\right)_{2}$ in the following study. The radiochemical yield of $\left.{ }^{99 \mathrm{~m} T c-(H a m-C y s}\right)_{2}$ was calculated by dividing the radioactivity of the collected two peaks by the radioactivity of the reaction mixture measured just before the HPLC purification, in accordance with our previous study ${ }^{11}$. The acquired ${ }^{99 m} \mathrm{Tc}-(\mathrm{Ham}-$ Cys) $)_{2}$ was analyzed by RP-HPLC using the same method described above. The radiochemical purity was calculated by dividing the radioactivity of the two peaks derived from the ${ }^{99 \mathrm{~m}} \mathrm{Tc}-(\mathrm{Ham}-\mathrm{Cys})_{2}$ by the total radioactivity acquired from the HPLC chart (Fig. 4A).

Radiolabeling of ${ }^{99 m}$ Tc-(Ham-RGD) ${ }_{2}$. To a solution of 6 (Ham-RGD, final concentration: $10 \mathrm{mM}$ ) in phosphate buffer ( $\mathrm{pH} 7.4,10 \mathrm{mM}, 50 \mu \mathrm{L}), 100 \mu \mathrm{L}$ of ${ }^{99 \mathrm{~m}} \mathrm{Tc}^{-N_{a T c O}}$ solution $(18-33 \mathrm{MBq})$ and $15 \mu \mathrm{l}$ of $3 \mathrm{mM}$ tin(II) tartrate hydrate solution in $\mathrm{H}_{2} \mathrm{O}$ were added. The reaction mixture was incubated at room tempera- 
ture for 10 min and purified by RP-HPLC on a YMC-Triart C18 (YMC CO., LTD., diameter: 4.6 mm, length: $150 \mathrm{~mm}$, particle size: $5 \mu \mathrm{m}$, pore size: $120 \AA$ ) using the mobile phase [10 mM phosphate buffer (pH 7.4)/acetonitrile $=80 / 20(0 \mathrm{~min})$ to $60 / 40(30 \mathrm{~min})]$ at a flow rate of $1.0 \mathrm{~mL} / \mathrm{min}$. The two peaks (retention time: around $13 \mathrm{~min}$, and around $15 \mathrm{~min}$ ) were collected, mixed, and used as ${ }^{99 \mathrm{~m}} \mathrm{Tc}-(\mathrm{Ham}-\mathrm{RGD})_{2}$ in the following study.

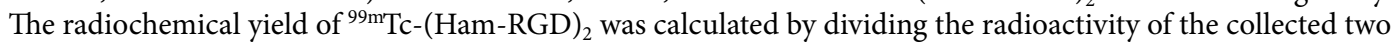
peaks by the radioactivity of the reaction mixture measured just before the HPLC purification, in accordance with our previous study ${ }^{11}$. The acquired ${ }^{99 \mathrm{~m}} \mathrm{Tc}-(\mathrm{Ham}-\mathrm{RGD})_{2}$ was analyzed by RP-HPLC using the same method described above. The radiochemical purity was calculated by dividing the radioactivity of the two peaks derived from the ${ }^{99 \mathrm{~m}} \mathrm{Tc}-(\mathrm{Ham}-\mathrm{RGD})_{2}$ by the total radioactivity acquired from the HPLC chart (Fig. 4B).

Cellular uptake study of ${ }^{99 m}$ Tc-(Ham-RGD) ${ }_{2}$. According to the previously reported study, U87MG human glioblastoma cells (DS Pharma Biomedical, Osaka, Japan) and PC3 human prostate carcinoma cells (DS Pharma Biomedical) were used as Integrin $\alpha_{v} \beta_{3}$ high- and low-expressing cells, respectively ${ }^{29}$. U87MG and PC3 cells were maintained in Dulbecco's modified Eagle's medium (DMEM) or Roswell Park Memorial Institute 1640 (RPMI 1640) containing 10\% fetal bovine serum, and $100 \mathrm{U} / \mathrm{mL}$ of penicillin and streptomycin in a $5 \%$ $\mathrm{CO}_{2}$ incubator at $37^{\circ} \mathrm{C}$. These cells were sub-cultured overnight in 12 -well plates $\left(4 \times 10^{5} \mathrm{cells} / 1 \mathrm{~mL}\right)$, and then pre-incubated in DMEM ( $1 \mathrm{~mL}$ ) with or without c(RGDfK) (final concentration: $10 \mu \mathrm{M})$ for 30 min at $37^{\circ} \mathrm{C}$ in a humidified atmosphere containing $5 \% \mathrm{CO}_{2}$. After the pre-incubation, the medium was exchanged with DMEM containing ${ }^{99 \mathrm{~m}} \mathrm{Tc}-(\mathrm{Ham}-\mathrm{RGD})_{2}(74 \mathrm{kBq}, 1 \mathrm{~mL})$ and then incubated for $60 \mathrm{~min}$. After the incubation, the cells were washed twice with phosphate-buffered saline (PBS) $(1 \mathrm{~mL})$ and then lysed with $1 \mathrm{M} \mathrm{NaOH}(0.4 \mathrm{~mL})$. The radioactivity in the lysates was measured by a Wallac WIZARD 2470 gamma counter (PerkinElmer, Waltham, MA, USA) and total protein concentrations in samples were measured using the bicinchonic acid method.

In vitro stability of ${ }^{99 \mathrm{~m}} \mathrm{Tc}$-(Ham-RGD) ${ }_{2}$ in mouse plasma. The in vitro stability of $\left.{ }^{99 \mathrm{~m} T c-(H a m-R G D)}\right)_{2}$ in mouse plasma was performed in accordance to our previous study with some modification ${ }^{11}$. In brief, ${ }^{99 \mathrm{~m}} \mathrm{Tc}-$ $(\mathrm{Ham}-\mathrm{RGD})_{2}$ (about $\left.500 \mathrm{kBq}\right)$ was added to prepared fresh murine plasma $(200 \mu \mathrm{L})$ collected from ddY mice (male, 5 weeks old). After incubating the solution at $37^{\circ} \mathrm{C}$ for 60 and $180 \mathrm{~min}$, acetonitrile $(200 \mu \mathrm{L})$ was added. Subsequently, the solution was centrifuged $(4000 \mathrm{~g}, 10 \mathrm{~min})$ and the supernatant was analyzed using RP-HPLC on a YMC-Triart C18 (YMC CO., LTD., diameter: $4.6 \mathrm{~mm}$, length: $150 \mathrm{~mm}$, particle size: $5 \mu \mathrm{m}$, pore size: $120 \AA$ ) using the mobile phase $[10 \mathrm{mM}$ phosphate buffer $(\mathrm{pH} 7.4) /$ acetonitrile $=80 / 20(0 \mathrm{~min})$ to $60 / 40(30 \mathrm{~min})]$ at a flow rate of $1.0 \mathrm{~mL} / \mathrm{min}$.

In vivo biodistribution of ${ }^{99 \mathrm{~m}} \mathrm{Tc}-(\mathrm{Ham}-\mathrm{RGD})_{2}$. Animal experiments were approved by the Kyoto University Animal Care Committee, and performed in accordance with ARRIVE guidelines (https://arriveguid elines.org) and the institutional guidelines for animal care of Kyoto University. BALB/c athymic nude mice (male, 5 weeks) supplied by Japan SLC, Inc. (Hamamatsu, Japan) were housed under a 12-h light/12-h dark cycle, and given free access to food and water. PC 3 cells $\left[5 \times 10^{6}\right.$ cells/0.1 mL of RPMI1640 and Geltrex (Thermo Fisher Scientific, Waltham, MA, USA) at a ratio of 1:1] were subcutaneously inoculated into the left flank of mice. At 2 weeks after the inoculation of PC 3 cells, U87MG cells $\left[5 \times 10^{6}\right.$ cells $/ 0.1 \mathrm{~mL}$ of DMEM and Geltrex (Thermo Fisher Scientific) at a ratio of 1:1] were subcutaneously inoculated into the right flank of mice, and a biodistribution study was performed after a 2 -week growth period. ${ }^{99 \mathrm{~m}} \mathrm{Tc}-(\mathrm{Ham}-\mathrm{RGD})_{2}(370 \mathrm{kBq} / 0.1 \mathrm{~mL}$ saline $)$ was injected intravenously into the tumor-bearing mice. Mice were sacrificed by decapitation at 5, 60, 180, and $360 \mathrm{~min}$ after administration. The tumor, blood, muscle, and other organs were then excised, and their radioactivity and weight were measured. For the blocking study, c(RGDfK) $(10 \mathrm{mg} / \mathrm{kg}$ weight) dissolved in $0.1 \mathrm{~mL}$ of saline was injected intravenously into the tumor-bearing mice. At $15 \mathrm{~min}$ after the injection of $\mathrm{c}(\mathrm{RGDfK})$, ${ }^{99 \mathrm{~m} T c}$-(Ham-RGD) $2(370 \mathrm{kBq} / 0.1 \mathrm{~mL}$ saline) was injected intravenously into the mice, which were sacrificed by decapitation at $180 \mathrm{~min}$ after administration. The tumor, blood, muscle, and other organs were then excised, and their radioactivity and weight were measured.

SPECT imaging. SPECT/CT imaging study was performed using a Triumph LabPET12/SPECT4/CT (TriFoil Imaging Inc., Chatsworth, CA, USA) by the previously reported method with modification ${ }^{30}$. ${ }^{99 \mathrm{mTc}}$ (Ham-RGD) 2 (2.8 MBq/0.1 mL saline) was injected intravenously into the tumor-bearing mice prepared by the above method. At 45 and 165 min after administration, the mice were anesthetized with $1.5-2.0 \%$ isoflurane for approximately $10 \mathrm{~min}$, and then CT imaging was performed with X-ray sources set to $60 \mathrm{kVp}$ and $360 \mu \mathrm{A}$. After CT imaging at 60 and 180 min after the administration of ${ }^{99 m} \mathrm{Tc}-(H a m-R G D)_{2}$, SPECT imaging was performed with multi-pinhole collimators ( $1.0 \mathrm{~mm}$ diameter) and the projection data were acquired using a $20 \%$ energy window centered at $140 \mathrm{keV}$ for ${ }^{99 \mathrm{~m}} \mathrm{Tc}$, with a $360^{\circ}$ circular orbit, 60 -s projection time, and 32 projection angles. The acquired SPECT data were reconstructed by a three-dimensional ordered subset expectation maximization (OSEM) algorithm with CT-based attenuation correction and then analyzed using Amide software (Amide.exe ver. 1.0.4, SourceForge.net, https://sourceforge.net/projects/amide/files/amide/1.0.4/).

Statistics. Data are presented as the mean \pm S.E.M (for the in vitro study) or the mean \pm S.D (for the in vivo study). In the in vitro study, statistical analyses were performed using 2-way ANOVA following the TukeyKramer test with JMP 14 software (SAS Institute Inc., Cary, NC, USA). For the in vivo study, the Student's $t$-test was used to assess the significance of differences. Differences at the $95 \%$ confidence level $(\mathrm{P}<0.05)$ were considered significant. 
Received: 7 June 2021; Accepted: 31 August 2021

Published online: 21 September 2021

\section{References}

1. Duatti, A. Review on 99mTc radiopharmaceuticals with emphasis on new advancements. Nucl. Med. Biol. 92, 202-216 (2021).

2. Liu, S. \& Edwards, D. S. 99mTc-labeled small peptides as diagnostic radiopharmaceuticals. Chem. Rev. 99, 2235-2268 (1999).

3. Banerjee, S. R. et al. New directions in the coordination chemistry of $99 \mathrm{mTc}$ : A reflection on technetium core structures and a strategy for new chelate design. Nucl. Med. Biol. 32, 1-20 (2005).

4. Papagiannopoulou, D. Technetium-99m radiochemistry for pharmaceutical applications. J. Label. Comp. Radiopharm. 60, 502-520 (2017).

5. Nakayama, M. et al. Hydroxamamide as a chelating moiety for the preparation of ${ }^{99 \mathrm{~m}}$ Tc radiopharmaceuticals (I). Nucl. $\mathrm{Med}$. Commun. 13, 445-449 (1992).

6. Nakayama, M. et al. Hydroxamamide as a chelating moiety for the preparation of $99 \mathrm{mTc}$ radiopharmaceuticals-II. The $99 \mathrm{mTc}$ complexes of hydroxamanide derivatives. Appl. Radiat. Isotopes 45, 735-740 (1994).

7. Nakayama, M. et al. Hydroxamamide as a chelating moiety for the preparation of $99 \mathrm{mTc}$-radiopharmaceuticals III. Characterization of various 99mTc-hydroxamamides. Appl. Radiat. Isotopes 48, 571-577 (1997).

8. Thipyapong, K., Yasarawan, N., Wanno, B., Arano, Y. \& Ruangpornvisuti, V. Conformational investigation of N, N'-propylene bis(benzohydroxamamide), its oxotechnetium(v) and oxorhenium(v) complexes and determination of their reaction energies. $J$. Mol. Struct. (Thoechem) 755, 45-53 (2005).

9. Iikuni, S. et al. Enhancement of binding affinity for amyloid aggregates by multivalent interactions of $99 \mathrm{mTc}$-hydroxamamide complexes. Mol. Pharm. 11, 1132-1139 (2014).

10. Iikuni, S. et al. Imaging of cerebral amyloid angiopathy with bivalent (99m)Tc-hydroxamamide complexes. Sci. Rep. 6, 25990 (2016).

11. Shimizu, Y. et al. Development of technetium-99m-labeled BODIPY-based probes targeting lipid droplets toward the diagnosis of hyperlipidemia-related diseases. Molecules 24, 2283 (2019).

12. Iikuni, S., Kitano, A., Watanabe, H., Shimizu, Y. \& Ono, M. Synthesis and evaluation of novel technetium-99m-hydroxamamide complex based on imidazothiadiazole sulfonamide targeting carbonic anhydrase-IX for tumor imaging. Bioorg. Med. Chem. Lett. 30, 127596 (2020).

13. Iikuni, S. et al. Development of the $(99 \mathrm{~m})$ Tc-hydroxamamide complex as a probe targeting carbonic anhydrase IX. Mol. Pharm. 16, 1489-1497 (2019).

14. Braband, H. High-valent techetium chemistry-new opportunities for radiopharmaceutical developments. J. Label. Comp. Radiopharm. 57, 270-274 (2014).

15. Ravasco, J., Faustino, H., Trindade, A. \& Gois, P. M. P. Bioconjugation with maleimides: A useful tool for chemical biology. Chemistry 25, 43-59 (2019).

16. Gurrath, M., Müller, G., Kessler, H., Aumailley, M. \& Timpl, R. Conformation/activity studies of rationally designed potent antiadhesive RGD peptides. Eur. J. Biochem. 210, 911-921 (1992).

17. Pearson, R. J., Kassianidis, E., Slawin, A. M. Z. \& Philp, D. Self-replication vs. reactive binary complexes-Manipulating recognitionmediated cycloadditions by simple structural modifications. Org. Biomol. Chem. 2, 3434-3441 (2004).

18. Desgrosellier, J. S. \& Cheresh, D. A. Integrins in cancer: Biological implications and therapeutic opportunities. Nat. Rev. Cancer 10, 9-22 (2010).

19. Pfaff, M. et al. Selective recognition of cyclic RGD peptides of NMR defined conformation by alpha IIb beta 3 , alpha V beta 3 , and alpha 5 beta 1 integrins. J. Biol. Chem. 269, 20233-20238 (1994).

20. Rabb, H., Barroso-Vicens, E., Adams, R., Pow-Sang, J. \& Ramirez, G. Alpha-V/beta-3 and alpha-V/beta-5 integrin distribution in neoplastic kidney. Am. J. Nephrol. 16, 402-408 (1996).

21. Shi, J., Wang, F. \& Liu, S. Radiolabeled cyclic RGD peptides as radiotracers for tumor imaging. Biophys. Rep. 2, 1-20 (2016)

22. Franken, P. R. et al. Distribution and dynamics of $99 \mathrm{mTc}$-pertechnetate uptake in the thyroid and other organs assessed by singlephoton emission computed tomography in living mice. Thyroid 20, 519-526 (2010).

23. Taira, Y. et al. Coordination-mediated synthesis of purification-free bivalent $(99 \mathrm{~m})$ Tc-labeled probes for in vivo imaging of saturable system. Bioconjug. Chem. 29, 459-466 (2018).

24. Uehara, T. et al. Manipulating pharmacokinetics of purification-free $(99 \mathrm{~m})$ Tc-labeled bivalent probes for in vivo imaging of saturable targets. Mol. Pharm. 17, 1621-1628 (2020).

25. Mizuno, Y. et al. Purification-free method for preparing technetium-99m-labeled multivalent probes for enhanced in vivo imaging of saturable systems. J. Med. Chem. 59, 3331-3339 (2016).

26. Mizuno, Y. et al. Aryl isocyanide derivative for one-pot synthesis of purification-free $(99 \mathrm{~m}) \mathrm{Tc}-\mathrm{labeled}$ hexavalent targeting probe. Nucl. Med. Biol. 86-87, 30-36 (2020).

27. Decristoforo, C. et al. [99mTc]HYNIC-RGD for imaging integrin alphavbeta3 expression. Nucl. Med. Biol. 33, 945-952 (2006).

28. Shimizu, Y. et al. Immunoglobulin G (IgG)-based imaging probe accumulates in M1 macrophage-infiltrated atherosclerotic plaques independent of IgG target molecule expression. Mol. Imag. Biol. 19, 531-539 (2017).

29. Piras, M. et al. High-affinity "click" RGD peptidomimetics as radiolabeled probes for imaging alphav beta3 integrin. ChemMedChem 12, 1142-1151 (2017).

30. Kimura, H. et al. Development of $(99 \mathrm{~m})$ Tc-labeled asymmetric urea derivatives that target prostate-specific membrane antigen for single-photon emission computed tomography imaging. Bioorg. Med. Chem. 24, 2251-2256 (2016).

\section{Acknowledgements}

We thank Mr. Takashi Nishimoto (Radioisotope Research Center, Agency of Health, Safety and Environment, Kyoto University, Kyoto, Japan) for his technical assistance in the SPECT imaging study. This study was supported by JSPS KAKENHI Grant Number 19K08096.

\section{Author contributions}

Y.S. contributed to the conception and overall experimental design and wrote the manuscript. M.O. contributed to the conception and experimental design. Y.S. and M.A. performed experiments and analyzed data. H.W., and S.I. advised on experimental design and analysis. All authors reviewed the manuscript.

\section{Competing interests}

The authors declare no competing interests. 


\section{Additional information}

Supplementary Information The online version contains supplementary material available at https://doi.org/ 10.1038/s41598-021-98235-X.

Correspondence and requests for materials should be addressed to Y.S. or M.O.

Reprints and permissions information is available at www.nature.com/reprints.

Publisher's note Springer Nature remains neutral with regard to jurisdictional claims in published maps and institutional affiliations.

(c) (i) Open Access This article is licensed under a Creative Commons Attribution 4.0 International License, which permits use, sharing, adaptation, distribution and reproduction in any medium or format, as long as you give appropriate credit to the original author(s) and the source, provide a link to the Creative Commons licence, and indicate if changes were made. The images or other third party material in this article are included in the article's Creative Commons licence, unless indicated otherwise in a credit line to the material. If material is not included in the article's Creative Commons licence and your intended use is not permitted by statutory regulation or exceeds the permitted use, you will need to obtain permission directly from the copyright holder. To view a copy of this licence, visit http://creativecommons.org/licenses/by/4.0/.

(C) The Author(s) 2021 